\title{
PELATIHAN PENGAKUAN, PENGUKURAN, DAN PENCATATAN ASET PADA MASYARAKAT PENGRAJIN SONGKET DI DESA MUARA PENIMBUNG ILIR
}

\author{
Efva Octavina Donata Gozali ${ }^{1}$ \\ Fakultas Ekonomi, Universitas Sriwijaya \\ email: efvagozali@unsri.ac.id \\ Agung Putra Raneo ${ }^{2}$ \\ Fakultas Ekonomi, Universitas Sriwijaya \\ email: agung.raneo@fe.unsri.ac.id \\ Ruth Samantha Hamzah ${ }^{3}$ \\ Fakultas Ekonomi, Universitas Sriwijaya \\ email: ruth_samantha@fe.unsri.ac.id \\ Anisa Listya ${ }^{4}$ \\ Fakultas Ekonomi, Universitas Sriwijaya \\ email: listya_anisa@fe.unsri.ac.id
}

\begin{abstract}
The main problem faced by songket business is capital constraint since they have poor knowledge about managing internal resources, namely assets. Hence, we offered solution to overcome the aforementioned problem by delivering knowledge in regard of assets in terms of its recognition, measurement and recording. The community service therefore aims to provide knowledge about the recognition, measurement, and recording of assets. This activity was addressed to community of songket business in Muara Penimbung Ilir, Ogan Ilir Regency, South Sumatra Province, Indonesia. Lecture and discussion as well as simulation and mentoring were used as the methods. This activity had been conducted for three months, started on August until October 2021, while the visits for training were given three times. The results indicate that after the training had been given, the songket businessman is equipped with knowledge of asset recognition, measurement and recording.
\end{abstract}

Keywords: Assets, Asset Recognition, Asset Measurement, Asset Recording, MSMEs

\section{ABSTRAK}

Permasalahan yang diangkat dalam kegiatan pengabdian masyarakat pengrajin songket adalah keterbatasan modal yang diakibatkan oleh minimnya pengetahuan mengenai sumber daya internal yaitu aset. Solusi yang diberikan adalah memberikan pemahaman yang baik kepada masyarakat pengrajin songket akan aset baik pengakuan, pengukuran dan pencatatannya. Kegiatan pengabdian masyarakat ini bertujuan untuk memberikan pengetahuan mengenai pengakuan, pengukuran, dan pencatatan aset. Kegiatan ini ditujukan kepada kelompok usaha masyarakat pengrajin songket di Desa Muara Penimbung Ilir, Ogan Ilir, Sumatera Selatan, Indonesia. Metode yang digunakan adalah ceramah dan diskusi yang disertai dengan pemberian simulasi dan pendampingan selama kurun waktu tiga bulan (Agustus-Oktober 2021). Kunjungan berupa pemberian materi pelatihan diberikan sebanyak tiga kali di waktu yang berbeda. Hasil dari kegiatan ini menunjukkan bahwa setelah diberikan pelatihan masyarakat 
pengrajin songket memiliki pengetahuan mengenai aset disertai cara pengakuan, pengukuran dan pencatatannya.

\section{Kata kunci: Aset, Pengakuan Aset, Pengukuran Aset, Pencatatan Aset, UMKM}

\section{PENDAHULUAN}

Berdasarkan KBBI aset merupakan kekayaan baik berupa uang ataupun wujud benda lainnya yang nyata. Disisi lain, aset dalam lingkup bisnis didefinisikan sebagai segala sesuatu yang dapat dimanfaatkan untuk mendukung kegiatan perusahaan selama lebih dari satu periode serta memiliki manfaat di masa mendatang (Asmara et al., 2020). Karena itu, di dalam bisnis pencatatan aset penting untuk dilakukan untuk mengetahui jumlah harta yang dimiliki agar perusahaan memiliki rasio keuangan yang sehat. Dalam akuntansi, aset yang tidak nyata secara fisik atau aset tidak berwujud juga diklasifikasikan ke dalam aset, selama harta tersebut memiliki manfaat ekonomi di masa mendatang yang biaya perolehannya dapat diukur secara andal (PSAK 19). Oleh karena itu, akuntansi melalui PSAK meregulasi ketentuan yang mengklasifikasikan aset ke dalam aset tetap dan aset tak berwujud (PSAK 16; PSAK 19).

Selanjutnya, khalayak sasaran dalam kegiatan ini adalah usaha mikro, kecil, dan mengengah (UMKM) khususnya pengrajin songket di Desa Muara Penimbung Ilir, Ogan Ilir, Sumatera Selatan. Untuk memudahkan UMKM dalam proses pencatatan dan penyusunan laporan keuangan Dewan Standar pada tahun 2016 menyusun Standar Akuntansi Keuangan Entitas Mikro, Kecil, dan Menengah (SAK EMKM) dalam membuat penilaian atas kemampuan entitas untuk melanjutkan usahanya di masa yang akan datang (kelangsungan usaha) (ED SAK EMKM, 2016). Entitas mempunyai kelangsungan usaha jika manajemen melikuidasi entitas tersebut atau menghentikan operasi atau tidak mempunyai alternatif realistis kecuali melakukan hal tersebut. Jika entitas tidak menyusun laporan keuangan berdasarkan asumsi kelangsungan usaha, maka entitas mengungkapkan fakta mengapa entitas tidak memiliki kelangsungan usaha.
Implementasi SAK tersebut mengharuskan perusahaan minimal memiliki laporan keuangan sederhana termasuk catatan akuntansi. Kenyataannya sebagian besar pelaku UMKM tidak memiliki administrasi yang baik sehingga mengakibatkan informasi keuangan yang dimiliki juga tidak baik. Hal yang melatarbelakangi kondisi tersebut adalah latar belakang pendidikan dan pengelolaan keuangan (Kurniawati et al., 2012).

Terkait dengan hal tersebut, kendala paling dominan yang menghambat UMKM untuk berkembang adalah kurangnya permodalan (Asmarani, 2006). Akses untuk memperoleh modal sebenarnya memiliki kelonggaran karena pemerintah pemerintah melalui kementerian UMKM telah menyediakan kredit usaha rakyat (KUR) bagi pelaku UMKM. Namun demikian, karena kondisi yang disebutkan di atas (i.e., informasi laporan keuangan yang minim), akses untuk memperoleh modal menjadi terkendala, karena otoritas pemberi pinjaman menjadi sangat berhati-hati untuk menggelontorkan kredit. Padahal UMKM, utamanya di Negara berkembang (termasuk Indonesia) secara kumulatif menyumbang PDB dalam jumlah fantastis, sehingga sering disebut sebagai penggerak roda perekonomian. Selain itu, UMKM memiliki keuanggulan seperti menciptakan lapangan pekerjaan yang lebih cepat dibandingkan sektor bisnis lain, memiliki fleksibilitas dan kemampuan menyesuaikan diri yang cepat terhadap kondisi pasar, dan mampu berkontribusi signifikan dalam ekspor dan perdagangan (Narsa et al., 2012).

Kemampuan UMKM dalam mencatat jumlah aset yang andal, UMKM akan mampu mengetahui besaran harta yang memang dimiliki oleh perusahaan sehingga dapat menghindari jumlah kewajiban yang melampaui besaran modal dan asetnya. Jumlah kewajiban yang melebihi besaran modal dan asetnya akan menyebabkan arus kas tersendat, jika arus kas terutama dari kegiatan operasional 
tidak lancar, maka kegiatan operasional akan terhambat dan pada jangka panjang akan mempengaruhi kestabilan kondisi keuangan perusahaan secara keseluruhan.

Dalam SAK EMKM pedoman mengenai aset diatur pada bab 11 dan 12 yang secara umum mengatur prinsip-prinsip pengakuan, pengukuran, penghentian pengakuan, dan penyajian aset tetap bagi aset tetap dan aset tak berwujud (ED SAK EMKM, 2016). Tujuan dari pencatatan aset yang dimulai dari pengakuan dan pengukurannya akan berguna bagi pengambilan keputusan sehingga aset tersebut dapat dimanfaatkan secara maksimal dengan efektif dan efisien. Kami mengadakan pelatihan ini kepada khalayak sasaran UMKM pengrajin songket di daerah tersebut dikarenakan songket merupakan kerajinan tradisional yang dikembangkan oleh masyarakat pribumi, sehingga sangat layak untuk dilestarikan dan dijaga keberlangsungannya. Secara tidak langsung, kegiatan ini mendukung kelestarian warisan budaya. Dalam jangka panjang kegiatan seperti ini harus dilaksanakan secara berkesinambungan untuk meningkatkan daya saing UMKM pengrajin songket di tengah gempuran fashion mode modern. Selain itu, kegiatan ini merupakan pendahuluan bagi UMKM agar mampu menyajikan laporan keuangan yang andal.

\section{METODE PELAKSANAAN}

Pelaksanaan kegiatan pengabdian pada masyarakat ini dilakukan dengan menggunakan metode ceramah, tutorial, diskusi, dan simulasi. Kegiatan ini telah dilaksanakan selama tiga kali kunjungan yaitu pada tanggal 20 Agustus, 23 September dan 1 Oktober 2021 pada kelompok usaha masyarakat pengrajin songket di Desa Muara Penimbung Ilir, Ogan Ilir, Sumatera Selatan. Selama selang waktu kunjungan dari kunjungan pertama ke kedua maupun kunjungan kedua ke ketiga, komunikasi intens terkait pelatihan tetap dilaksanakan secara daring. Hal ini berguna untuk memantau perkembangan pengetahuan peserta dalam mengakui, mengukur dan mencatat asset.

Adapun sistematika pelaksanaan kegiatan pengabdian ini dimulai dengan metode ceramah, pada langkah ini peserta diberikan motivasi agar memiliki kemauan untuk menggunakan akuntansi dalam kegiatan bisnisnya. Selanjutnya peserta diberikan tutorial berupa materi gambaran umum tentang akuntansi, standar akuntansi yang ada di Indonesia, pengenalan laporan keuangan secara umum, lalu akun-akun yang ada di laporan keuangan, serta pengakuan, pengukuran dan pencatatan akun aset. Langkah ketiga dilakukan setelah pemberian materi dilakukan, yaitu diskusi. Pada tahap ini peserta diberikan kesempatan untuk mendiskusikan permasalahan yang berkaitan dengan aset. Langkah terakhir adalah simulasi yaitu peserta diberikan kesempatan untuk mengelompokkan aset, membuat pengakuan, pengukuran dan pencatatan akun aset.

Pada tahap terakhir dilakukan evaluasi kegiatan pengabdian menggunakan kuisioner yang dibagikan kepada seluruh peserta. Evaluasi ini berguna sebagai perbaikan berkelanjutan dari kegiatan yang telah dilaksanakan, sehingga diharapkan kegiatan yang akan datang dapat dilaksanakan dengan mempertimbangkan hasil evaluasi dari kegiatan ini.

\section{HASIL DAN PEMBAHASAN}

Kegiatan pengabdian masyarakat mengenai pengakuan, pengukuran, dan pencatatan aset ini dilakukan kepada kelompok usaha masyarakat pengrajin songket di Desa Muara Penimbung Ilir, Kabupaten Ogan Ilir, Provinsi Sumatera Selatan. Kegiatan ini berlangsung selama kurang lebih tiga bulan sejak bulan Agustus sampai dengan Oktober 2021. Pada pelaksanaannya, rangkaian kegiatan pelatihan ini melakukan sebanyak tiga kali kunjungan kepada mitra pengabdian. Hal ini dilakukan untuk memastikan bahwa pengabdian masyarakat yang dilakukan sesuai dengan sasaran sehingga memperoleh manfaat bagi masyarakat pengrajin songket. Selain itu, terkait pandemi Covid-19 yang masih mewabah di wilayah Sumatera Selatan, setiap kunjungan diselenggarakan dengan mematuhi standar protokol kesehatan untuk mencegah transmisi penyebaran virus pada saat kegiatan berlangsung. 
Kunjungan pertama dilakukan pada tanggal 20 Agustus 2021. Pada kunjungan ini dilakukan sesi diskusi dengan beberapa perwakilan masyarakat terkait solusi dari kendala yang dihadapi para pelaku usaha pengrajin songket di daerah ini. Secara umum, kendala dan hambatan yang dihadapi oleh pelaku usaha pengrajin songket terkait pengelolaan aset adalah mereka tidak melakukan pemisahan aset yang dimiliki oleh usaha dan pribadi. Hal ini diakibatkan karena para pelaku usaha tidak secara regular mendata aset atau harta yang berasal dari kegiatan usaha. Terkait dengan alasan tersebut, khusus untuk aset tetap, sebagian besar pelaku usaha tidak mencatat penurunan nilai buku aset yang diakibatkan oleh penyusutan aset. Sehingga mereka tidak mengetahui kapan peralatan tersebut telah habis masa pakainya sehingga telah layak untuk diganti.

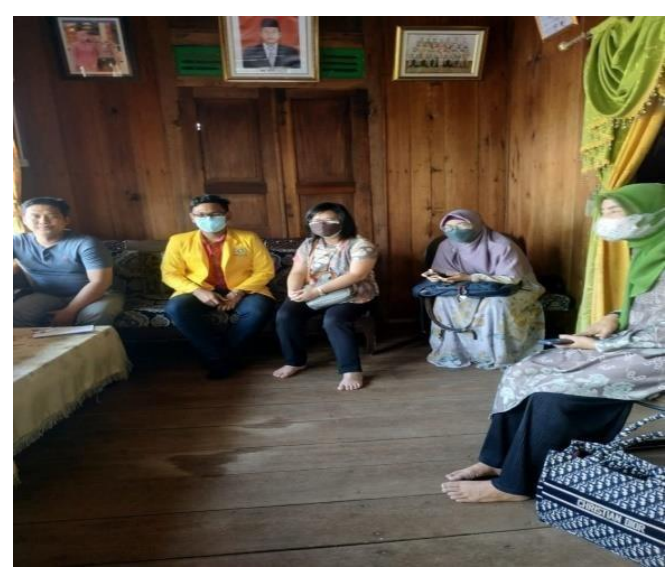

Gambar 1. Sesi Diskusi pada Kunjungan Pertama

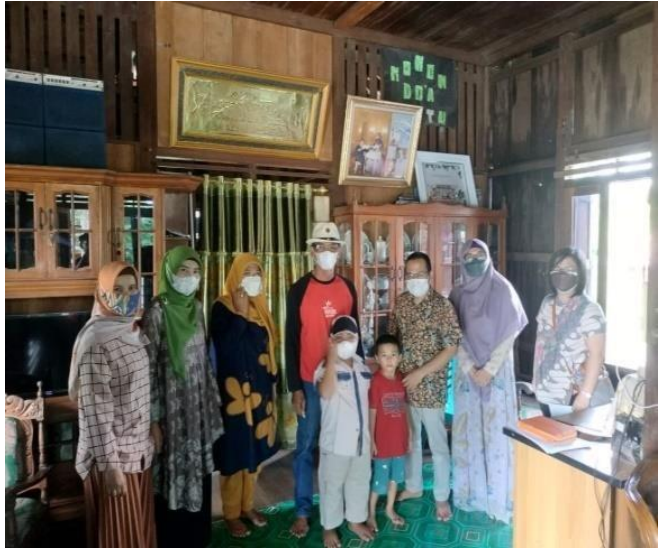

\section{Gambar 2. Dokumentasi Kunjungan Pertama}

Dari hasil kunjungan pertama dirancang strategi dalam upaya mengurangi kendala yang dihadapi pelaku usaha terkait aset. Karena itu, kunjungan kedua yang telah diselenggarakan pada tanggal 23 September 2021 lebih menekankan pada penginternalisasian mindset pelaku usaha agar terbuka terhadap konsep business entity dimana setiap pelaku usaha wajib melakukan pencatatan terkait kegiatan usaha dan pencatatan tersebut dilakukan secara individual atau terpisah dari kegiatan pribadi. Setelah pelaku usaha memahami konsep tersebut, materi mengenai pengakuan, pengukuran dan pencatatan aset mulai diberikan per tahapan dan dipaparkan dalam bahasa yang sederhana agar mudah dipahami oleh masyarakat umum. Karena itu, kegiatan pada kunjungan kedua dibagi menjadi tiga sesi yaitu pendalaman materi, simulasi, dan diskusi.

Peserta pada kunjungan kedua merupakan kelompok usaha masyarakat pengrajin songket.

Kegiatan ini dihadiri oleh 27 peserta yang terdiri dari 8 peserta laki-laki $(30 \%)$ dan 19 peserta perempuan (70\%) (gambar 3). Rangkaian kunjungan kedua dilaksanakan di salah satu rumah warga Desa Muara Penimbung Ilir yang dilaksanakan sejak pukul 09.00 hingga pukul 15.00 WIB. 


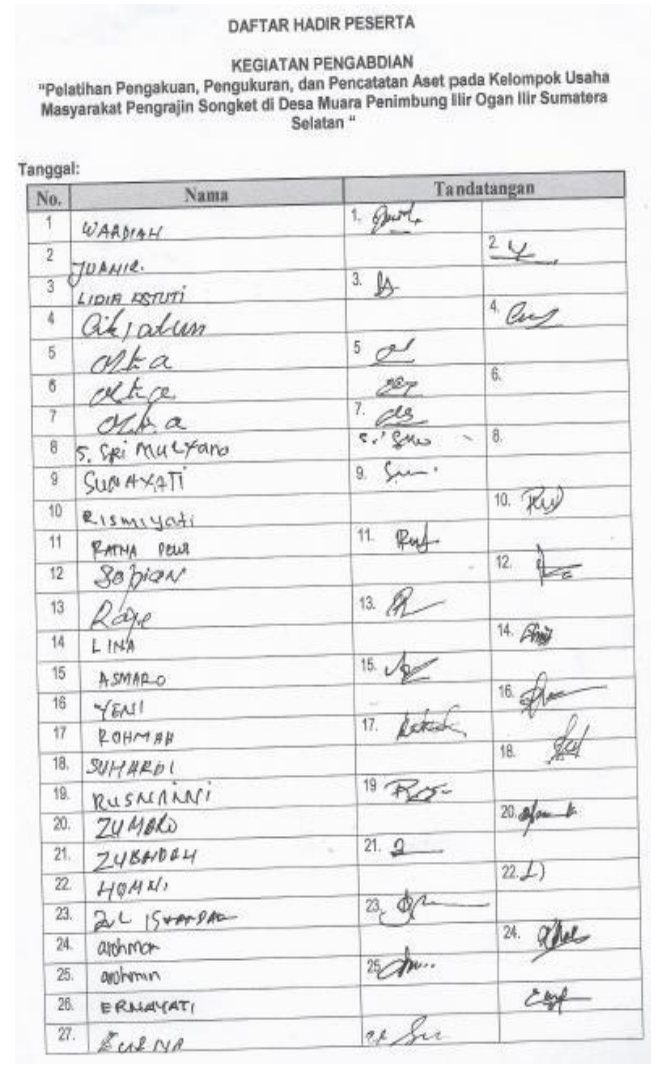

Gambar 3. Daftar Hadir Peserta Kunjungan Kedua

Pada sesi pertama, materi yang dijelaskan adalah mengenai klasifikasi aset, pengakuan aset, pengukuran aset dan pencatatan aset. Sesi pertama menghabiskan waktu sekitar 1 jam. Setelah sesi pertama selesai, dilanjutkan dengan simulasi. Pada sesi ini, peserta dapat mereplika tahapan simulasi dengan mengisi modul pada bagian simulasi yang sebelumnya telah dibagikan. Peserta dapat mengisi modul sesuai dengan contoh yang diberikan instruktur atau menyesuaikannya dengan aset usaha songket yang mereka miliki. Apabila terdapat kendala terkait simulasi pengisian modul, peserta langsung dibantu oleh tim kegiatan pengabdian. Sehingga pada sesi terakhir yaitu diskusi dan tanya jawab, para peserta lebih banyak bertanya terkait kasus yang terjadi pada usaha mereka terkait aset seperti, (1) bagaimana jika peralatan yang mereka gunakan diperbaiki sehingga dapat digunakan kembali, (2) apakah peralatan yang tidak terpakai lagi masih dapat diakui sebagai aset, (3) bagaimana cara menentukan harga aset (pengukuran) jika tidak diketahui lagi berapa harga perolehannya. Pertanyaan ini merupakan pertanyaan fundamental terkait aset, oleh karena itu, instruktur menjelaskan sembari mengaitkan kembali dengan materi yang telah diberikan pada sesi pertama.

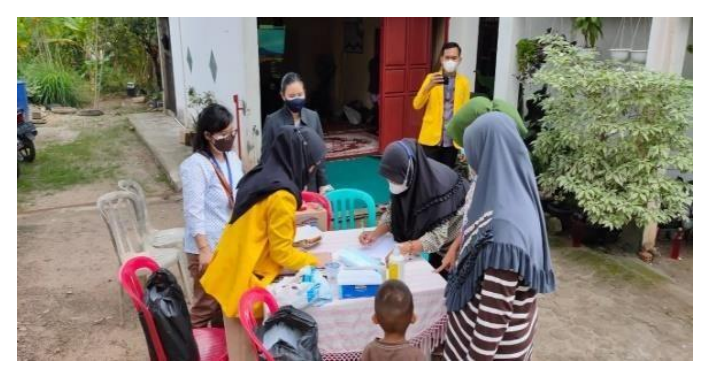

\section{Gambar 4. Peserta Mengisi Daftar Hadir}

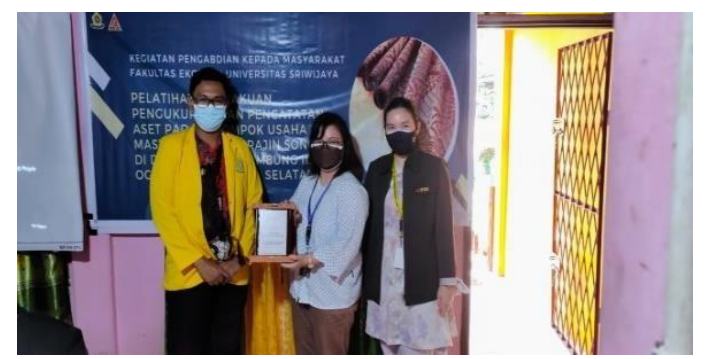

Gambar 5. Dokumentasi Kunjungan Kedua

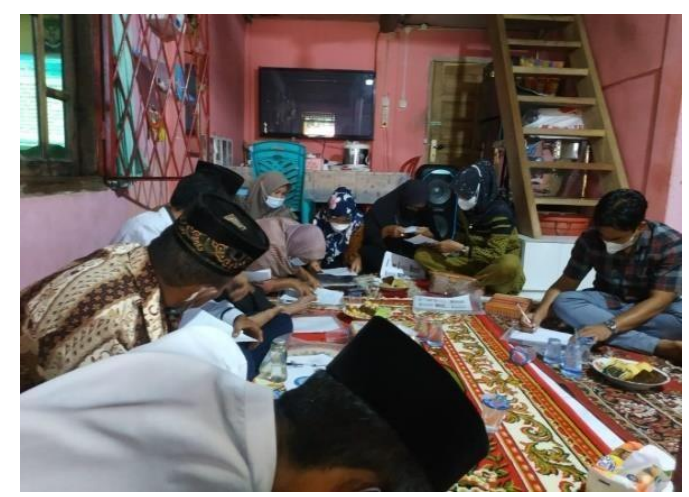

Gambar 6. Kegiatan Kunjungan Kedua

Kunjungan ketiga merupakan bagian dari pemantauan dan evaluasi dari rangkaian kegiatan pengabdian masyarakat. Pada kunjungan ini, metode yang dilaksanakan berupa diskusi. Sehingga, dapat diketahui masalah dan kendala yang masih timbul setelah penerapan pengakuan, pengukuran, dan pencatatan aset bagi usaha mereka. Pada kunjungan ini lembar kuisioner dibagikan kepada para peserta. Kuisioner ini dijadikan evaluasi sebagai perbaikan berkelanjutan bagi 
kegiatan pengabdian masyarakat ini, serta digunakan untuk menampung saran dan kritik yang membangun dari para peserta. Hasil dari lembar evaluasi ditampilkan pada tabel 1 .

Tabel 1. Lembar Hasil Evaluasi Kegiatan Pengabdian

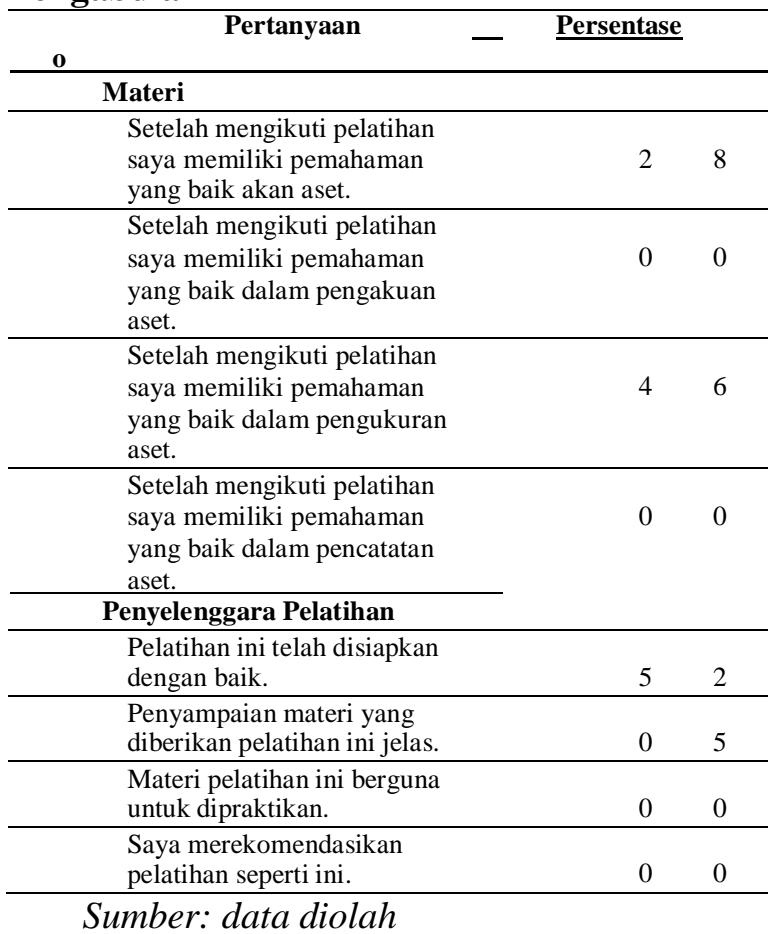

Kuisioner ini menggunakan nilai 1-4, dimana $1=$ sangat tidak setuju, $2=$ tidak setuju, $3=$ setuju, 4=sangat setuju. Dari lembar hasil kuisioner ini sebagian besar peserta memiliki pemahaman yang baik mengenai aset dengan nilai setuju sebesar $42 \%$ dan sangat setuju sebesar $58 \%$ setelah mengikuti rangkaian kegiatan pelatihan pengakuan, pengukuran dan pencatatan aset. Poin pertanyaan lain dari kuisioner ini juga menunjukkan bahwa mayoritas peserta (90\%) sangat merekomendasikan jika pelatihan berkelanjutan diadakan di daerah mereka.

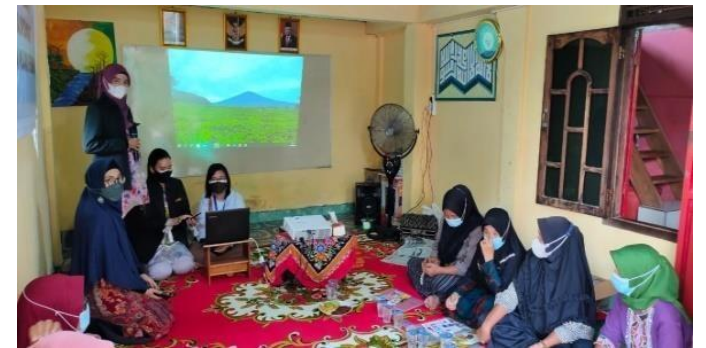

Gambar 7. Dokumentasi Kunjungan Ketiga

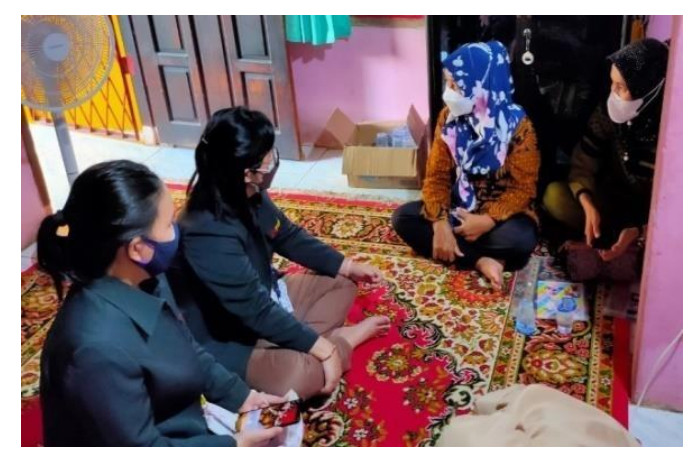

Gambar 8. Kegiatan Kunjungan Ketiga

\section{SIMPULAN}

Hasil evaluasi kegiatan pengabdian masyarakat mengindikasi bahwa seluruh peserta sudah memiliki pemahaman yang baik akan aset baik pengakuan, pengukuran dan pencatatannya. Metode ceramah, simulasi, diskusi, serta pendampingan cocok untuk diterapkan pada kelompok usaha masyarakat pengrajin songket di Desa Muara Penimbung Ilir. Kegiatan pengabdian kepada masyarakat ini dapat memberikan manfaat secara langsung maupun tidak langsung kepada masyarakat pengrajin songket di Desa Muara Penimbung Ilir. Dengan memiliki pengetahuan akan aset yang mumpuni, kegiatan pengabdian masyarakat selanjutnya yang direkomendasikan di Desa Muara Penimbung Ilir adalah mengenai pengelolaan aset. Pada akhirnya tujuan dari kegiatan pengabdian masyarakat sejenis di Desa Muara Penimbung Ilir adalah mitra mampu membuat laporan keuangan yang baik dan benar untuk usaha mereka. Sehingga, dengan memiliki kemampuan menyusun laporan keuangan yang baik dan regular modal eksternal akan lebih mudah diakses, dengan modal yang lebih besar diharapkan para pengrajin songket di Desa Muara Penimbung 
Ilir mampu memperluas pangsa pasar usaha mereka.

\section{UCAPAN TERIMA KASIH}

Segenap tim pengabdian masyarakat mengucapkan terima kasih kepada masyarakat pengrajin songket dan Kepala Desa Muara Penimbung Ilir atas antusiasme yang diberikan terhadap kegiatan ini. Selanjutnya, ucapan terima kasih kepada LPPM Universitas Sriwijaya sebagai penyokong dana pengabdian masyarakat ini.

\section{REFERENSI}

[1]. Asmarani, D. E. (2006). Analisis Pengaruh Perencanaan Strategi terhadap Kinerja Perusahaan dalam Upaya Menciptakan Keunggulan Bersaing (studi empirik pada Industri Kecil Menengah tenun ikat di Troso, Jepara). Undip Semaramg, 112.

[2]. Asmara, F., Agustina, Y. (2020). Evaluasi Perlakuan Akuntansi Aset Tetap Pada CV Sarana Adi Putra Periode 2017 s/d 2018. Jurnal Riset Akuntansi, Volume 12 (1), 95-104.

[3]. Ikatan Akuntan Indonesia. 2013. Entitas Tanpa Akuntabilitas Publik. Jakarta: Dewan Standar Akuntasi Keuangan.

[4]. Ikatan Akuntan Indonesia (IAI). 2009. Standar Akuntansi Keuangan Entitas
Tanpa Akuntabilitas Publik ( SAK ETAP). Jakarta: Dewan StandarAkuntansi Keuangan Ikatan Akuntan Indonesia.

[5]. Ikatan Akuntan Indonesia (IAI). (2016). Standar Akuntansi Keuangan Entitas Mikro, Kecil, dan Menengah. SAK EMKM Ikatan Akuntan Indonesia, 4, 154.

http://iaiglobal.or.id/v03/files/draft_ed_ sak_emkm_kompilasi.pdf

[6]. Ikatan Akuntan Indonesia (IAI). (2020). Standar Akuntansi Keuangan. Salemba Empat.

[7]. Kurniawati, E., Nugroho, P., \& Arifin, C. (2012). Penerapan Akuntansi Pada Usaha Mikro Kecil Dan Menengah (Umkm). Jurnal Manajemen Dan Keuangan Darmajaya, 10(2), 218956.

[8]. Narsa, I. M., Widodo, A., \& Kurnianto, S. (2012). Mengungkap Kesiapan Umkm Dalam Implementasi Standar Akuntansi Keuangan Entitas Tanpa Akuntabilitas Publik ( Psak-Etap ) Untuk Meningkatkan Akses Modal Perbankan. Majalah Ekonomi, 3, 204-214.

[9]. PSAP, No 07. 2010. Akuntansi Aset Tetap. Presiden Republik Indonesia. Lembaran Negara Republik Indonesia Tahun 2010, No. 123. Jakarta: Sekretariat Negara. 